\title{
ASSESSING THE NATURAL HAZARD OF GULLY EROSION THROUGH A GEOECOLOGICAL INFORMATION SYSTEM (GEIS): A CASE STUDY FROM THE WESTERN CARPATHIANS
}

\begin{abstract}
SAKSA, M., MINÁR, J. (2012): Assessing the natural hazard of gully erosion through a Geoecological Information System (GeIS): a case study from the Western Carpathians. Geografie, 117, No. 2, pp. 152-169 (2012). - The development of gullies represents a specific type of fluvial erosion that is triggered when surface runoff becomes concentrated during extreme rainfall events. This study investigates a part of the Považské Valley and Strážovské Mountains in Slovakia to assess the potential susceptibility and gully erosion hazard using a Geoecological Information System (GeIS). The landscape of the area was studied through primary field research and the analysis of secondary materials. The GeIS was then constructed in order to undertake specific multidimensional statistical methods. These were used to assess the potential susceptibly and gully erosion hazard. Those areas with the greatest potential susceptibility occur in Butkovská Furrow and the Podmanínska Hills whilst those with the least potential susceptibility occur in Butkovské Klippes and the Trenčianska Upland. The greatest gully erosion hazard was identified on arable land in the Podmanínska Hills and on the river terraces in the Ilavská Basin. It is clear that the majority of the permanent gullies within the study area are controlled by the course of existing anthropogenic linear features such as unpaved field and forest roads and balks in arable land. KEY WORDS: natural hazard - gully erosion - abiocomplex - multidimensional statistical methods - Geoecological Information System - Western Carpathians.
\end{abstract}

This work was supported by the Slovak Research and Development Agency under the contract ESF-EC-0006-07.

\section{Introduction}

The development of gullies represents a specific type of fluvial erosion that is triggered when surface runoff becomes concentrated on parts of a slope during extreme rainfall events (Zachar 1960). These gullies commonly develop as deeply incised features in soft sedimentary materials such as the loess of Belgium (Nachtergaele, Poesen 1999; Nachtergaele et al. 2002) and marls of southern Spain (Harvey, Wells 1987). The process of gully erosion is known to be accelerated by human activities and unfortunately the type of material it affects are often highly fertile and used for agricultural purposes. Therefore, the creation of deeply incised gullies represents a highly significant problem in arable areas. It affects the soil production capacity, damages unpaved roads, and leads to barriers in communication. This may result in unusable agricultural land and ultimately the development of badlands. The development of gullies clearly represents a specific type of natural hazard. 
In many respects, gully erosion is more dangerous and destructive than either sheet or rill erosion. The soil displaced by sheet or rill erosion is deposited close to its original source, usually at the foot of the adjacent slope. The material detached by gully erosion is transported far further from its original source. It is usually deposited on nearby roads or is taken into sewerage systems and then deposited in reservoirs (Fulajtár, Janský 2001). Many modern studies from Australia, China, Ethiopia, and the USA demonstrate that the majority of reservoir sediments derive from processes connected with gully erosion (Valentin, Poesen, Yong Li 2005). In its broadest sense, gully erosion may also include the erosion of unpaved roads and tracks. This is generally considered to be direct anthropogenic erosion caused by pedestrians and vehicles (Fulajtár, Janský 2001). It results, however, from interactions between of all the aforementioned types of erosion upon the surface of the road. In the Middle Ages, medieval roads were cut deeply into slopes and this gave rise to hollow ways or sunken lanes. These sunken lanes may attain depths of up to 5 metres, and therefore represent an advanced stage of gully erosion.

The aim of this study is to assess the gully erosion hazard by combining empirical data, geoecological information system, and multidimensional statistical methods. The benefit of combining a geoecological database with multidimensional statistical methods in order to assess the gully erosion hazard represents the most innovative aspect of this study. The majority of published methods that aim to assess the gully erosion hazard are based on the use of existing analytical information about the landscape; the applicability of these methods is sometimes questionable when detailed investigations are being conducted. Furthermore, deterministic analytical methods are being used more frequently. In contrast to other types of natural hazard assessment, the potential benefits offered by multidimensional statistical methods are rarely considered in studies that assess the gully erosion hazard. It has been shown that the use of a comprehensive geoecological database provides a good basis for a synthetic hazard evaluation (Minár et al. 2006). The use of multidimensional statistical methods in natural hazard assessment was originally applied in the 1980s (e.g. Carrara 1983, 1988). These statistical methods are commonly used to assess flood hazard (e.g. Nathan, McMahon 1990; Ouarda et al. 2001). In Slovakia, such methods have been used to assess landslide hazard (Pauditš, Vlčko, Jurko 2005; Bednárik, Pauditš 2009; Bednárik et al. 2010). Furthermore, they have also been used to estimate the influence of local conditions on the overall impact of a windstorm within a forest located in the foothills of the High Tatra Mountains (Faltan et al. 2009; Minár et al. 2009).

\section{Study area}

The area considered in this study covers $36 \mathrm{~km}^{2}$ and incorporates elements of the Považské Valley and Strážovské Mountains, northwestern Slovakia (Fig. 1). This area forms part of the Western Carpathians. It includes five distinct physiographic regions and each has a different susceptibility to gully erosion (Ilavská Basin, Butkovská Furrow, Butkovské Klippes, Podmanínska Hills, and Teplická Upland). In the Western Carpathians, the most dense gully networks are associated with hills and lower uplands; these areas represent transitional 


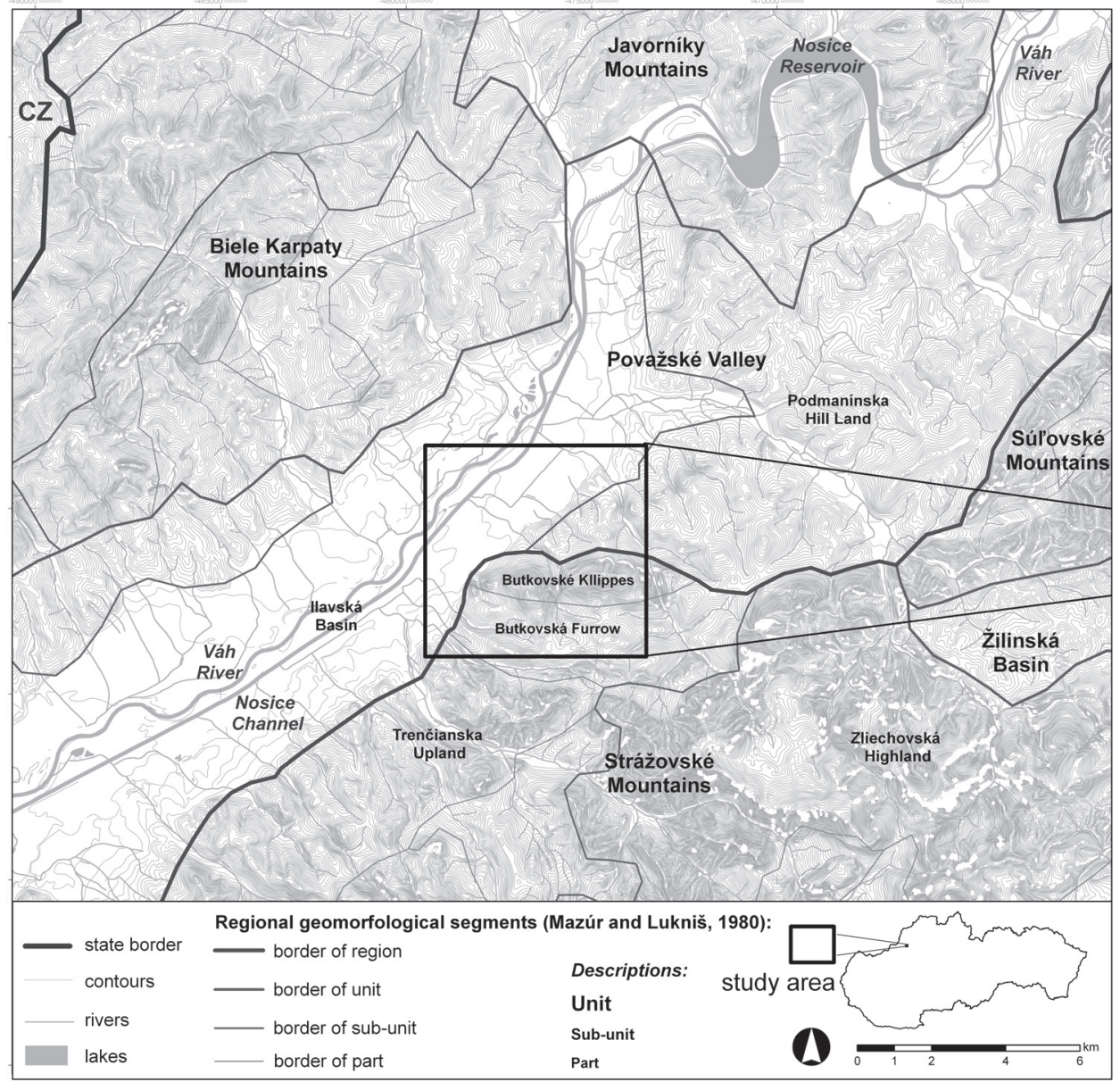

Fig. 1 - Location of the study area

zones between the mountains and valleys. They are generally characterised by rock complexes with low resistance to overland flow processes (Stankoviansky 2003a). Apart of natural factors also the human activity (especially different land uses in the historical and present time) played a significant role in the development and spatial distribution of linear erosion forms (Kliment 2003). The gully erosion is represented by ephemeral gullies. These can be levelled by ploughing but may then reappear in the same place following the next storm event. The larger permanent gullies represent relic forms. These cannot be removed by regular cultivation and clearly originated under the different climatic and land use conditions that existed before collectivisation. They have usually been stabilised by forest vegetation and form conspicuous islands of trees within the agricultural landscape. Despite this stabilisation, limited signs of gully erosion may occasionally reappear (Stankoviansky 2003b). 


\section{Methods}

The presented study was undertaken in three different stages. First, the landscape of the area was studied through primary field research and the analysis of secondary materials. Second, a geodatabase was constructed in order to undertake specific multidimensional statistical methods. Third, these statistical methods were then used to assess the potential susceptibly and gully erosion hazard within the study area.

The first stage of the study collated information relating to the physical characteristics of the region. This included both primary field research and analysing secondary data sources. The former comprised collecting data on the nature of the soil cover and mapping land cover and land use, evidence of gully erosion, and linear features that may be prone to gully erosion. The latter included the analysis of, for example, geological and soil maps. The results of this stage have been collated in the Geoecological Information System.

\subsection{The Geoecological Information System (GeIS)}

The second stage of the study involved the construction of a specific type of geodatabase termed the Geoecological Information System (GeIS). It is a special Geographical Information System (GIS) that integrates the geoecological data necessary for assessing the gully erosion hazard (Minár 2003). The GeIS is an environment that enables data collection, storage, and processing. For the purpose of this study, the GeIS was constructed in the platform ArcGIS ${ }^{\mathrm{TM}}$.

The most important step in constructing the GeIS is to synthesise the selected landscape components in order to accurately determine the boundaries and characteristics of each abiocomplex. They are the basic units used to assess gully erosion susceptibility across the study area and their delimitation is based on the concept of elementary relief forms (Minár, Evans 2008). The abiocomplexes are relatively homogeneous areas in terms of their geoecological conditions and each is associated with a set of characteristics that may influence the onset of gully erosion. They were defined through analyses of the morphometric relief characteristics generated from the DTM and the soil unit boundaries obtained from the General Survey of Agricultural Soils of Slovakia.

The dry channels of ephemeral streams, unpaved field and forest roads, and balks in arable land are linear features considered to be prone to gully erosion. In the field, the degree of gully erosion was assessed according to the character of the surface or by the symptoms of road erosion. The basic attributes of the layer containing the permanent gullies includes the overall area of the gully, its depth, and its level of activity. The latter is estimated from the character of its base and walls as well as traces left by flowing water. The basic attributes of the layer containing the sunken lanes layer includes their overall length, depth, and the degree of activity. The sunken lanes were classified into two types and a standardised width of $3 \mathrm{~m}$ was assigned to the "classic" sunken lanes (e.g. field or forest roads) and a width of $2 \mathrm{~m}$ was assigned to the logging roads or skid trails. 
The GeIS contains the following data types:

1. Basic topographic layers (excerpts).

- Raster layers of the basic topographical map 1:10,000. These comprise topography, altimetry, water, vegetation, and descriptions (C) Geodetic and Cartographic Institute 2002).

- Aerial orthophotomaps (C) EUROSENSE 2005; (C) GEODIS Slovakia 2006).

- Historical military topographic maps 1:10,000 (ㄷ) Geodetic and Cartographic Institute 1962).

2. Digital Terrain Model (DTM).

- DTM generated from point heights based on the contours of the basic topographic map 1:10,000 (Podmanínska Hills and Strážovské Mountains).

- DTM generated from aerial survey photographs using photogrammetric methods (Ilavská Basin).

3. Derived morphometric relief characteristics.

- Raster data layers generated from the DTM. These comprise slope angle, slope length, slope aspect, profile curvature, plan curvature.

4. Data layers on rock environment and soils (excerpts).

- Regional geological map of Central Považie 1:50,000 (C Geological Institute).

- General survey of agricultural soils of Slovakia (C) Soil Science and Conservation Research Institute, Bratislava).

- Land evaluation units (C) Soil Science and Conservation Research Institute, Bratislava).

- Detailed Forest Soil Survey (C) National Forest Centre, Zvolen).

5. Data obtained by field research.

- Analytical data on relief, soils, and rocks.

- Data on existing evidence of gully erosion, e.g. permanent gullies, sunken lanes, and other linear that maybe prone to gully erosion such as tracks and forest roads.

6. Land cover and land use.

- Vector data layer constructed on base orthophotomaps.

7. Boundaries of the abiotic complexes (abiocomplexes).

- The basic spatial units that represent the study area for the assessment of the gully erosion hazard.

8. Database abiotic complexes (abiocomplexes).

- The basic database of abiotic data used for the gully erosion assessment consists of the following geoecological (abiotic) characteristics:

a. Geological substrate

b. Lithogeographic situation

c. Morphological-morphometric landform type

d. Genetic soil representative

e. Soil texture of topsoil or surface horizon

f. Soil texture of subsoil or subsurface horizon

g. Stoniness of topsoil or surface horizon

h. Stoniness of subsoil or subsurface horizon

i. Soil depth

j. Slope inclination

k. Slope length

1. Profile curvature

m. Plan curvature 
n. Geometric relief forms

o. Slope aspect

\subsection{Multidimensional statistical methods}

The third stage of the study involved undertaking multidimensional statistical methods. The assessment of natural hazards using multidimensional statistical methods is usually less accurate that it is when using physical models (Lineback et al. 2001) and resulting maps are not altogether intelligible for laymen (Clerici et al. 2002). The advantages of such statistical methods in the assessment of natural hazards are that they can be applied objectively over large areas, they are less demanding in terms of time, and they require less input information (Saksa, Kriegerová 2005).

The initiation of gully erosion is determined by the characteristics of the abiocomplexes and land cover and land use. The susceptibility of the study area to gully erosion was first considered without reference to land cover and land use. This is referred to as its potential susceptibility and it has been investigated using multidimensional statistical methods and a physically based conceptual model (Minár, Tremboš 1994). The dependence between individual characteristics of the abiocomplexes and the existing evidence of gully erosion was investigated through multiple regression analysis. In addition, cluster analysis combined with component analysis for the regionalisation of individual abiocomplexes determined their potential susceptibility to gully erosion. The resulting potential susceptibility relies on the simple assumption that the greater the area covered by gullies and sunken lanes within the defined abiocomplexes, the more likely it is that new gullies will form in the future. The aforementioned conceptual model expresses the relative gully erosion hazard as a function of slope length, slope inclination, and rock resistance (Minár, Tremboš 1994).

The Denudation Index (IDn, $\mathrm{m}^{3} / \mathrm{m}^{2}$ ) resulting from gully erosion (Fig. 3a) and the ratio between the area covered by gullies and sunken lanes to the total area of the abiocomplex (RT, \%; Fig. 3b) were calculated for each individual abiocomplex. These indexes both represent real evidence of gully erosion in the study area. The Denudation Index gives a maximum estimate of the sediment volume removed from the existing gullies and sunken lanes by gully erosion, recalculated to the area of the given abiocomplex:

$$
I D n=I D n_{(v)}+I D n_{(u)} / \mathrm{p}_{\mathrm{a}},
$$

where: $\mathrm{p}_{\mathrm{a}}\left[\mathrm{m}^{2}\right]$ - area of abiocomplex and

$$
\begin{aligned}
& I D n_{(v)}=p_{(v 1)} \cdot h_{(v 1)}+p_{(v 2)} \cdot h_{(v 2)}+\ldots+p_{(v n)} \cdot h_{(v n)} \\
& I D n_{(u)}=d l_{(u 1)} \cdot h_{(u 1)} \cdot s_{(u 1)}+d l_{(u 2)} \cdot h_{(u 2)} \cdot s_{(u 2)}+\ldots+d l_{(u n)} \cdot p_{(u n)} \cdot s_{(u n)},
\end{aligned}
$$
where:

$p_{(v 1 \ldots n)}\left[\mathrm{m}^{2}\right]$ - area of individual gullies within an abiocomplex

$h_{(v 1 \ldots n)}[\mathrm{m}]$ - depth of individual gullies within an abiocomplex while the maximum depth of each gully considered

$d l_{(u 1 \ldots n)}[\mathrm{m}]$ - length of individual sunken lanes within an abiocomplex

$h_{(u 1 \ldots n)}[\mathrm{m}]$ - depth of individual sunken lanes within an abiocomplex while the maximum depth of each gully considered 
$s_{(u 1 \ldots n)}[\mathrm{m}]$ - width of individual sunken lanes within an abiocomplex while a standardised width of $3 \mathrm{~m}$ was assigned to the "classic" sunken lanes and a width of $2 \mathrm{~m}$ was assigned to the logging roads

$I D n_{(v)}\left[\mathrm{m}^{3}\right]$ - Index of Denudation by gully erosion

$I D n_{(u)}\left[\mathrm{m}^{3}\right]$ - Index of Denudation by road erosion

IDn $\left[\mathrm{m}^{3} / \mathrm{m}^{2}\right]$ - Index of Denudation (overall) by gully erosion for a unit of abiocomlex area $\left[1 \mathrm{~m}^{2}\right]$

The multidimensional statistical methods only work with numerical values and the independent variables of the abiocomplex database are expressed by various means (e.g. text, number, code). It was, therefore, decided to parameterise them as follows. For each of the geoecological abiotic categories, the total percentage area covered by gullies and sunken lanes was calculated for the given category and then in relation to the total area of the given category with respect to the total study area:

$$
\text { par }=\frac{p\left(v_{1} \ldots v_{n}\right)+p\left(u_{1} \ldots u_{n}\right)}{P\left(K \mathrm{i}_{j}\right)} \times 100 \%
$$

where: $\mathrm{p}_{(\mathrm{v1} 1 \ldots \mathrm{vn})}\left[\mathrm{m}^{2}\right]-$ area of all gullies in the $j$-th category $i$-th characteristic $\mathrm{p}_{(\mathrm{u} 1 \ldots \mathrm{un})}\left[\mathrm{m}^{2}\right]-$ area of all sunken lanes in the $j$-th category $i$-th characteristic $\mathrm{P}\left(\mathrm{K}_{\mathrm{j}}^{\mathrm{i}}\right)\left[\mathrm{m}^{2}\right]$ - total area of the $j$-th category $i$-th characteristic

par - proportion of the area of gullies and sunken lanes to the total area of the $j$-th category of the $i$-th characteristic.

The numerical values of the geoecological characteristics where parameterisation was not indispensable (e.g. DTM derived morphometric characteristics, stoniness, soil depth) were also parameterised. We thus obtain two entry datasets for analysis. First, a set of all the parameterised characteristics. Second, a set with original qualitative parameterised characteristics and original quantitative non-parameterised characteristics.

Thereafter, an attempt was made to estimate the potential susceptibility of the study area to future gully erosion. This susceptibility does not consider the protective effects of the land cover and land use. The following four methodical procedures were analysed:

a) multiple regression analysis of entry dataset 2 , the parameterised qualitative and non-parameterised quantitative characteristics (RA, Fig. 3c)

b) cluster analysis of the entry dataset 1: all parameterised characteristics (CA1, Fig. 3d)

c) cluster analysis of the entry dataset 2 : the parameterised qualitative and non-parameterised quantitative characteristics (CA2, Fig. 3e)

d) conceptual physical based model by Minár and Tremboš (1994; MT; Fig. 3f):

$$
V=S . D / L
$$

where $V$ is the relative gully erosion hazard, $S$ is the slope inclination factor, $\mathrm{D}$ is the rock resistance factor, and $L$ is the slope length factor.

Using the RA model, the highest value of determination coefficient $\left(\mathrm{R}^{2}=36 \%\right)$ was obtained when the Index of Denudation (IDn) was used as the independent variable with entry dataset 2 . Meanwhile, the selection of abiocomplexes was limited to those areas where IDn $>0 \mathrm{~m}^{3}$. The following model was obtained: 


$$
I D n=-8390.53+4147.2 \times g e o k v \_p a r-19277.1 \times p l a n \_M I N+2521.83 \times t y p r \_p a r
$$

where:

geokv_par - the value of parameterised values of the lithogeographic situation plan_MIN - the value of minimal numerical values of the profile curvature

typr_par - the value of the parameterised values of the morphological-morphometrical landform types.

Models CA1 and CA2 were produced via the component and cluster analyses as the determination coefficient was somewhat low. FuzME software was used to automatically perform the cluster analysis using the fuzzy clustering method based on component analysis. The fuzzy exponent $(\geq 1)$ was 1.3 and the algorithm Fuzzy K Means was used. The last model is a relatively independent physical model and it represents a non-statistical way of assessing the potential erosion. As it is independent on the parameterisation outlined in the previous models, it could be used as a certain comparative standard.

The results of the individual analyses and models have been compared inter se as well as with the actual evidence for gully erosion. The latter were expressed by the ratio between the area covered by gullies and sunken lanes to the total area of the abiocomplex (RT) and the Denudation Index (IDn). This represents the maximum estimate of the volume of sediments removed by gully erosion processes from the existing gullies and sunken lanes recalculated to the area of the given abiocomplex.

The final assessment of the actual gully erosion hazard was undertaken through comparing the obtained potential susceptibility results with the current land cover and land use. The arable land within abiocomplexes with high susceptibility potential and the linear features with evident signs of erosion are the most threatened.

\section{Results}

The constructed Geoecological Information System is shown in Figure 2. Linear erosion forms in the study area are mostly linked to abiocomplexes with inclination $9-16^{\circ}$ and mainly concave and linear relief forms (slopes, dells). At very steep and short slopes the variability of erosion features and the density of linear erosion network are limited or missing because erosion is hampered by the short distance of concentrated runoff, hard rock outcrops and common occurrence of rock resistant to weathering (Kliment 2003). From the geological point of view most linear forms are associated with polygenetic and loess loams and deluvial sediments developed from flysch rocks.

The results of all the undertaken means of gully erosion assessment are shown in Figure 3. These have been compared inter se (Table 2) and with the evidence for gully erosion within the study area, represented by the Denudation Index (IDn; Table 1) and the ratio between the area covered by gullies and sunken lanes to the total area of the abiocomplex (RT; Table 3).

The comparison of the results was preceded by the targeted categorisation of the IDn and RT. The results were divided into five categories. This ensured that each of the categories was regularly represented across the study area. The chosen method was that of quantiles. For the results obtained from the 


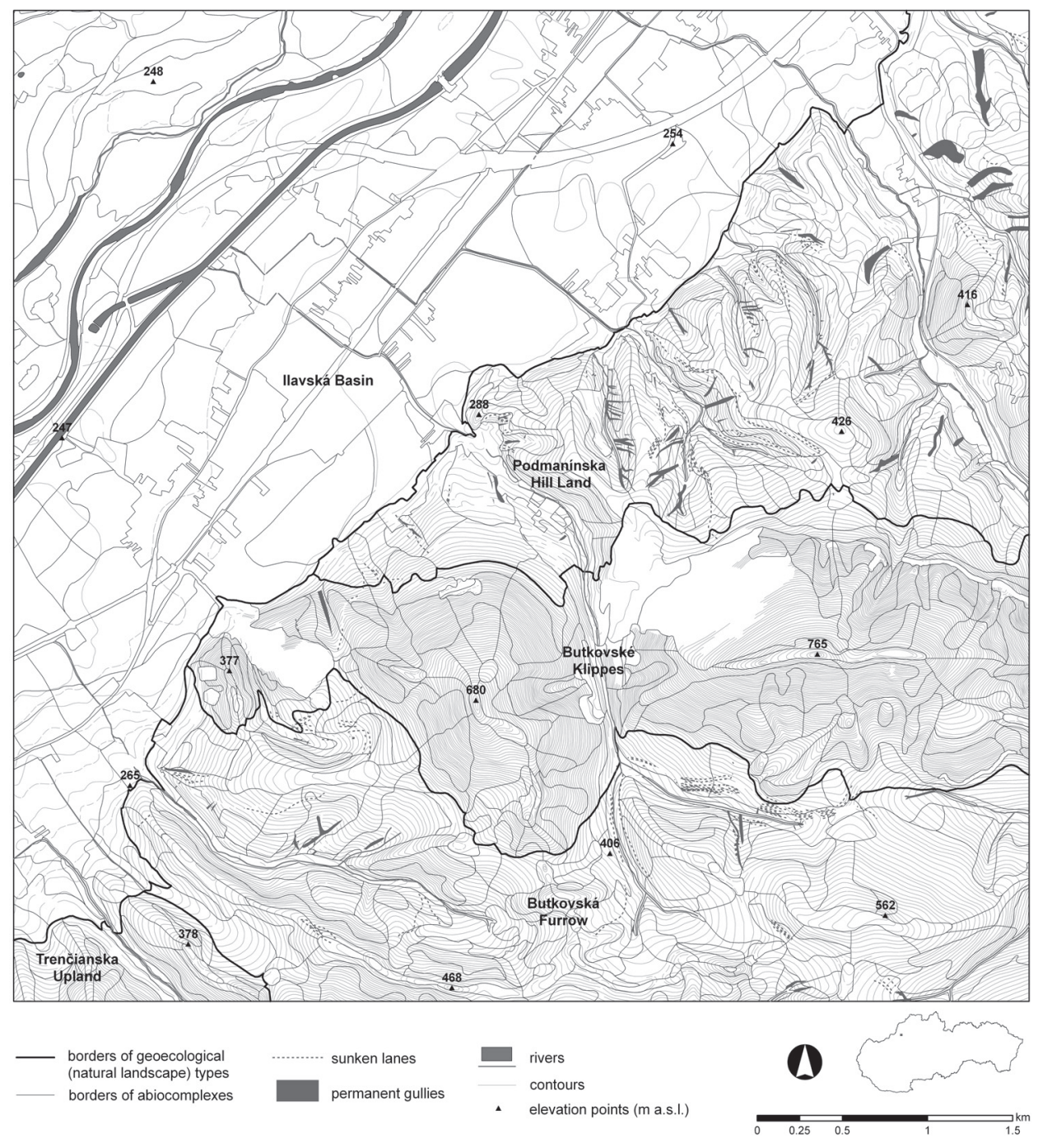

Fig. 2 - The abiocomplexes, permanent gullies, and sunken lanes located within the study area

five categories in the cluster analysis were graded according to the percentage of actual evidence of gully erosion in individual clusters (IDn and RT).

Two basic procedures were used to compare the compatibility of the obtained results:

1. The simple linear regression correlation coefficients between the four methods were used to assess the potential susceptibility of the study area to future gully erosion (Tabs. 1 and 2).

2. The mean deviation of results between the four methods was used to assess the potential susceptibility of the study area to future gully erosion and the actual evidence for gully erosion (Tab. 3). 
Tab. 1 - The simple linear regression correlation coefficients between the four methods used to assess the potential susceptibility of the study area to future gully erosion and the actual evidence for gully erosion

\begin{tabular}{|lcccc|}
\hline & RA & CA1 & CA2 & MT \\
\hline Denudation Index (IDn) & 0.41 & 0.50 & 0.07 & 0.30 \\
$\begin{array}{l}\text { Ratio between area covered by gullies \& sunken lanes } \\
\text { to the total area of the abiocomplex (RT) }\end{array}$ & 0.43 & 0.50 & 0.07 & 0.31 \\
\hline
\end{tabular}

Tab. 2 - The simple linear regression correlation coefficients between the four methods used to assess the potential susceptibility of the study area to future gully erosion applied inter se

\begin{tabular}{|l|cccc|}
\hline & RA & CA1 & CA2 & MT \\
\hline RA & - & 0.78 & 0.11 & 0.66 \\
CA1 & 0.78 & - & 0.10 & 0.64 \\
CA2 & 0.11 & 0.10 & - & 0.05 \\
MT & 0.66 & 0.64 & 0.05 & - \\
\hline
\end{tabular}

Tab. 3 - The mean deviation of results between the four methods used to assess the potential susceptibility of the study area to future gully erosion and the actual evidence for gully erosion (in a single 5-grade scale)

\begin{tabular}{|lcccc|}
\hline & RA & CA1 & CA2 & MT \\
\hline $\begin{array}{l}\text { Denudation Index (IDn) } \\
\begin{array}{l}\text { Ratio between area covered by gullies \& sunken lanes } \\
\text { to the total area of the abiocomplex (RT) }\end{array}\end{array}$ & 1.57 & 1.30 & 1.89 & 1.58 \\
\hline
\end{tabular}

The model generated by cluster analysis with a set of parameterised characteristics (CA1; Fig. 3d) comes closest to the reproducing the real evidence for gully erosion presented in Figs. 3a and 3b. It not only shows the highest correlation with the actual evidence, but also the lowest mean error between individual categories. In contrast, the lowest correlation and the highest mean error occurs in the model generated by cluster analysis with a set of all the parameterised and non-parameterised characteristics (CA2; Fig. 3f, Tabs. 1 and 3). It is, evidently, caused by the modification of the generated clusters that occurs when the low susceptibility abiocomplexes are divided into two distinct categories. However, the inclusion of the non-parameterised entry characteristics may also play a role as these logically reduce the homogeneity of the results of the cluster analysis with evidence of gully erosion.

The simple linear regression correlation coefficients between the four methods were used to assess the potential susceptibility of the study area to future gully erosion applied inter se. Relatively high correlations occur when the coefficient exceeds 0.5 . It shows that the correlation is higher than it is when the potential erosion models were compared to the actual evidence of gully erosion. This can be interpreted to result from the difference between the potential and actual susceptibility of abiocomplexes to gully erosion. It should be noted that the most significant factors to influence the actual susceptibility are that of land cover and land use and the presence of linear features. An extremely 
a)

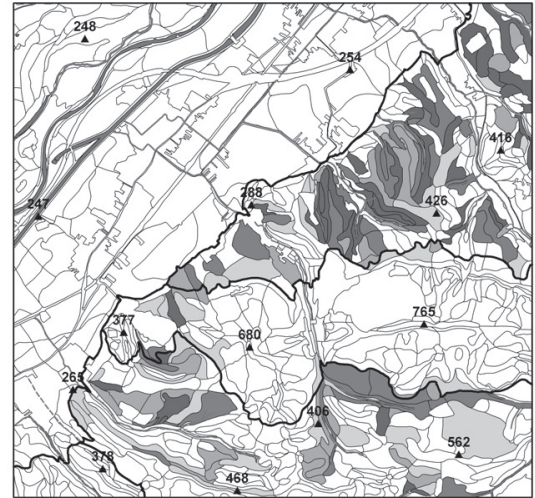

Denudation Index (IDn) $\left[\mathrm{m}^{3} / \mathrm{m}^{2}\right]$ :

$\square 0.000000 \square 0.000001-0.011545 \square 0.011546-0.050509$ $0.050510-0.216556$

c)

c)

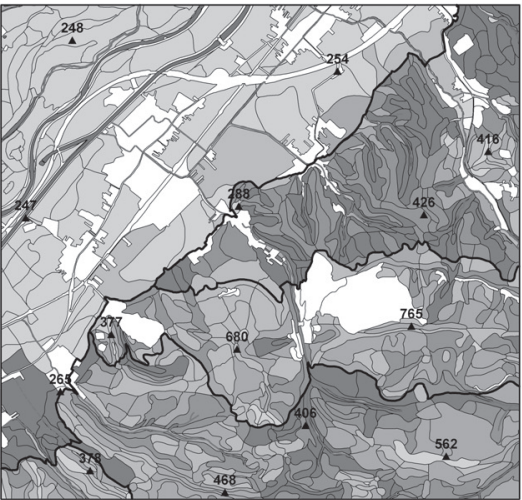

e)

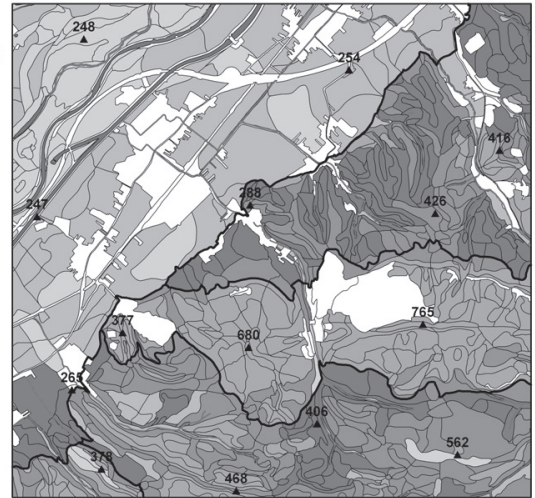

b)

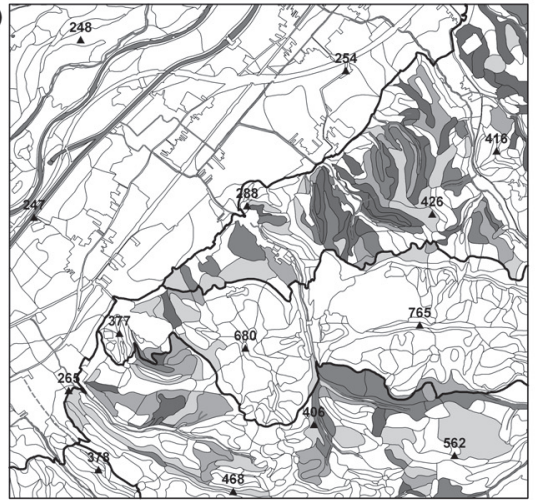

Ratio between the area covered by gullies and sunken lanes to the total area of the abiocomplex (RT) [\%]:

$0.00 \square 0.01-0.61 \square 0.62-2.54$
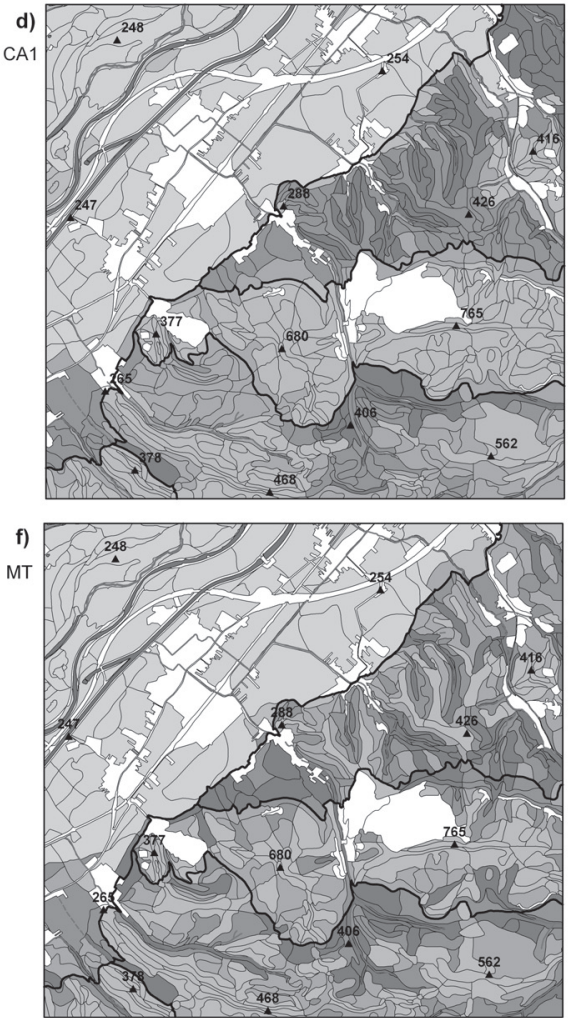

The potential gully erosion hazard:

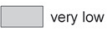

$\square$ low

medium $\square$ high

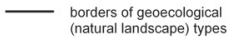

rivers

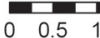

very high

elevation points ( $m$ a.s.l.)

Fig. 3 - (a) Denudation Index (IDn; $\mathrm{m}^{3} / \mathrm{m}^{2}$ ); (b) ratio between the area covered by gullies and sunken lanes to the total area of the abiocomplex (RT; \%); (c-f) the potential gully erosion hazard: (c) RA; (d) CA1; (e) CA2; (f) MT. 


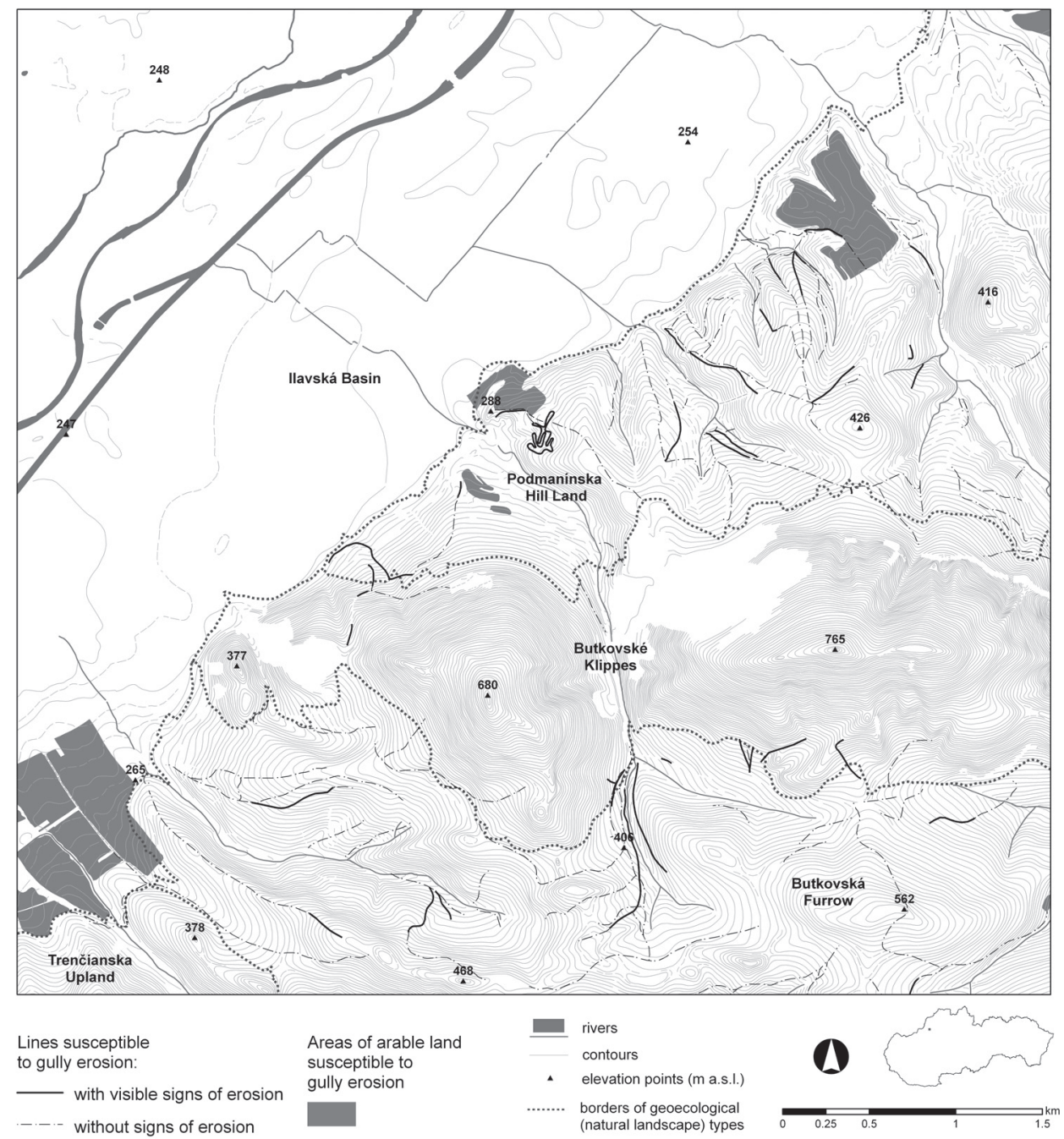

Fig. 4 - The actual gully erosion hazard

high correlation $\left(R^{2}=97 \%\right)$ between these two factors suggests that the applied method of quantiles used to categorise the values was a suitable choice.

In the final phase, the actual gully erosion hazard has been assessed. In this, the land cover and land use was also considered. The susceptibility can be expressed both in planar and linear terms (Fig. 4). The areas of arable land that occur on abiocomplexes with a high or very high potential susceptibility to gully erosion are normally found to be susceptible to gully erosion irrespective of the method applied. The field and forest roads as well as some other linear features including sunken lanes show both actual evidence of erosion and a high susceptibility to future gully erosion. Those sections with low inclinations, such as all unpaved field roads on flat terrain or forest roads that follow the contours, were excluded. 
It is clear that the majority of the permanent gullies within the study area are controlled by the course of existing anthropogenic linear features such as unpaved field and forest roads and balks in arable land. A small number of minor gullies have formed at the head of eroded incisions into small watercourses. These are interpreted to reflect the presence of ephemeral streams during humid periods. The occurrence of sunken lanes under permanent forest cover demonstrates that the processes of road erosion as the first stage of gully erosion is not necessarily limited to agricultural areas. Based on the obtained results, it is seen that the areas with the greatest potential susceptibility occur in Butkovská Furrow, Podmanínska Hills, and on the river terraces in the Ilavská Basin. Those with the least potential susceptibility occur in Butkovské Klippes, Trenčianska Upland, and on the flat floodplain of the Váh River. Podmanínska Hills are associated with the greatest number of permanent gullies and this may be attributable to exhaustive farming in the past. Fewer permanent gullies exist in Butkovská Furrow and this may be attributable to the widespread forests within this area. Nonetheless, sunken lanes generated by road erosion abound within the forests.

The greatest gully erosion hazard was identified on arable land in the Podmanínska Hills and on the river terraces in the Ilavská Basin. In both areas, the abiocomplexes are characterised by high or very high potential susceptibility whilst the linear features show clear signs of gully erosion.

\section{Discussion}

In assessing natural hazards, the landscape may be viewed as a set of discrete objects threatened to differing degrees by the specific hazard or as a set of influencing and influenced fields (Minár 2009). The first approach was chosen as the basis of this study through the application of abiocomplexes. It is especially appropriate for the contrasting landscapes of the study area. The entry data is homogenised during the construction of the GeIS and the process of parameterising the qualitative and quantitative characteristics is simple and efficient. In general terms, the application of the GeIS and multidimensional statistical methods have proved to be very suitable tools for the assessment of the natural hazards including that of gully erosion as presented in this study. The approach outlined here can be modified so that it is applicable over far larger areas than it has been for the detailed study presented here. The geoecological unification of the input data enables the method to form part of a synthetic natural hazards evaluation (Minár et al. 2006).

The simplest ways of expressing the gully erosion hazard are provided by the Denudation Index (Fig. 3a) and the ratio between the area covered by gullies and sunken lanes to the total area of the abiocomplex (Fig. 3b). These assume that the characteristics of gully erosion are spatially and temporally stable. This assumption is somewhat difficult to justify as it is known that the process of gully erosion may be accelerated by human activities (e.g. through deforestation or changes in land use). When such changes occur, the evidence for gully erosion may also change significantly. It is, therefore, important to study the potential erosion susceptibility of the abiocomplexes. The fundamental characteristics of the abiocomplexes do not incorporate land cover and land use and therefore 
these spatial units change more slowly in terms of their potential erosion susceptibility. The three multidimensional statistical methods used to assess the gully erosion hazard (RA, CA1, CA2) were all based on the parameterised characteristics of the abiocomplexes. The results produced by each statistical method were consistent. Moreover, there were significant correlations between two of them (RA, CA1) and the physically based conceptual model (MT). This suggests that the applied multidimensional statistical methods were able to distinguish between the potential and the actual erosion.

The simple assumption that the recorded evidence of erosion results from high abiotic erosion potential and certain types of land use was used as the basis the determining gully erosion susceptibility within the study area. As a result, only those areas previously subject to gully erosion are considered to be susceptible to further erosion. In contrast, those areas not previously subject to gully erosion are not going to be susceptible to erosion. Clearly, if erosion preventative measures pertaining to land cover and land use have been undertaken then the eroded area may actually be stable. For this reason, those areas with the greatest evidence for erosion (Figs. 3a and 3b) differ slightly from the actual gully erosion hazard (Fig. 4). The moderate correlations between the evidence of gully erosion and the selected geoecological characteristics is explained by the fact that gully erosion processes depend on a number of geoecological characteristics (e.g. lithology, soil, morphometric relief characteristics). The process of gully erosion is known to be accelerated by human activities such as the construction of roads. It is also likely to proceed more rapidly in soft sedimentary material such as loess, polygenetic loams, or slope sediments (especially in flysch rocks).

\section{Conclusions}

The development of gullies represents a specific type of fluvial erosion triggered when surface runoff becomes concentrated during extreme rainfall events. The application of the GeIS and multidimensional statistical methods has provided a suitable framework within which to assess this natural hazard in the Považské Valley and Strážovské Mountains in the Western Carpathians.

- It is clear that the majority of the permanent gullies within the study area are controlled by the course of existing anthropogenic linear features such as unpaved field and forest roads and balks in arable land.

- It is seen that the areas with the greatest potential susceptibility occur in Podmanínska Hills, Butkovská Furrow, and on the river terraces in the Ilavská Basin. Those with the least potential susceptibility occur in Butkovské Klippes, Trenčianska Upland, and on the flat floodplain of the Váh River.

- The greatest gully erosion hazard was identified on arable land in the Podmanínska Hills and on the river terraces in the Ilavská Basin. In both areas, the abiocomplexes are characterised by high or very high potential susceptibility whilst the linear features show clear signs of gully erosion.

It is thought that future changes in the global climate will increase the amount of heavy rainfall events. This will accelerate the process of gully erosion and increase its significance as a natural hazard. It is important that local 
geoecological conditions are understood so that the area can continue to be farmed and managed in a sustainable way.

\section{References:}

BEDNÁRIK, M., MAGULOVÁ, B., MATYS, M., MARSCHALKO, M. (2010): Landslide susceptibility assessment of the Kralovany - Liptovský Mikuláš railway case study. Physics and Chemistry of the Earth, 35, No. 3-5, pp. 162-171.

BEDNÁRIK, M., PAUDITŠ, P. (2009): Different ways of landslide geometry interpretation in a process of statistical landslide susceptibility and hazard assessment: Horná Súča (western Slovakia) case study. Environmental Earth Sciences, 61, No. 4, pp. 733-739.

CARRARA, A. (1983): Multivariate models for landslide hazard evaluation. Mathematical Geology, 5, No. 3, pp. 403-427.

CARRARA, A. (1988): Landslide hazard mapping by statistical method: a black box approach. Proceedings of the Workshop on Natural Disaster in European Mediterranean Countries, Consiglio Nazionale delle Richerche, Perugia, Italy, pp. 205-224.

CLERICI, A., PEREGO, S., TELLINI, C., VESCOVI, P. (2002): A procedure for landslide susceptibility zonation by the conditional analysis method. Geomorphology, 48, No. 4, pp. 349-364.

FALT̃AN, V., KATINA, S., BÁNOVSKÝ, M., PAZÚROVÁ, Z. (2009): The influence of site conditions on the impact of windstorms on forests: The case study of the High Tatras foothills (Slovakia) in 2004. Moravian Geographical Reports, 17, No. 3, pp. 44-52.

FULAJTÁR, E., JANSKÝ, L. (2001): Vodná erózia pôdy a protierózna ochrana. VÚPOP, Prírodovedecká Fakulta UK, Bratislava, 310 pp.

HARVEY, A.M., WELLS, S.G. (1987): Response of Quaternary fluvial systems to differential epeirogenic uplift: Aguas and Feos River Systems. Geology, 15, No. 8, pp. 689-693.

KLIMENT, Z. (2003): Lineární eroze v povodí Manětínského potoka. Geomorfologický sborník 2, ZCUU Plzeň, pp. 95-106.

LINEBACK, M.G., MARCUS, W.A., ASPINALL, R., CUSTER, S.G. (2001): Assessing landslide potential using GIS, soil wetness modeling and topographic attributes, Payette River, Idaho. Geomorphology, 37, No. 1-2, pp. 149-165.

MINÁR, J. (2003): Detailed physical-geographical (geoecological) research and mapping in the landscape ecology. Ekológia (Bratislava), 22, Supplement 2/2003, pp. 141-149.

MINÁR, J. (2009): Geografické polia a priestorová organizácia krajiny (pokus o vyjasňovanie základných konceptov). Geografický časopis, 61, No. 3, pp. 179-198.

MINÁR, J., BARKA, I., JAKÁL, J., STANKOVIANSKY, M., TRIZNA, M., URBÁNEK, J. (2006): Geomorphological hazards in Slovakia. Studia Geomorphologica CarpathoBalcanica, XL, pp. 61-78.

MINÁR, J., EVANS, I.S. (2008): Elementary forms for land surfaces segmentation: the theoretical basis of terrain analysis and geomorphological mapping. Geomorphology, 95, No. 3-4, pp. 236-259.

MINÁR, J., FALŤAN, V., BÁNOVSKÝ, M., DAMANKOŠOVÁ, Z., KOŽUCH, M. (2009): Influence of site conditions on the windstorm impact: a case study of the High Tatras foothills in 2004. Landform Analysis, 10, pp. 95-101.

MINÁR, J., TREMBOŠ, P. (1994): Prírodné hazardy - hrozby, niektoré postupy ich hodnotenia. Acta Facultatis rerum naturalium Universitatis Comenianae, Geographica, 35, Univerzita Komenského, Bratislava, pp. 173-194.

NACHTERGAELE, J., POESEN, J. (1999): Assessment of soil losses by ephemeral gully erosion using high-altitude (stereo) aerial photographs. Earth Surface Processes and Landforms, 24, No. 8, pp. 693-706.

NACHTERGAELE, J., POESEN, J., OOSTWOUD WIJDENES, D. VANDEKERCKHOVE, L. (2002): Medium term evolution of a gully developed in a loess-derived soil. Geomorphology, 46, No. 3-4, pp. 223-239.

NATHAN, R.J., McMAHON, T.A. (1990): Identification of homogeneous regions for the purposes of regionalization. Journal of Hydrology, 121, No. 1-4, pp. 217-238. 
OUARDA, T.B.M.J., GIRARD, C., CAVADIAS, G.S., BOBÉE, B. (2001): Regional flood frequency estimation with canonical correlation analysis. Journal of Hydrology, 254, No. 1-4, pp. 157-173.

PAUDITŠ, P., VLČKO, J., JURKO, J. (2005): Využívanie štatistických metód pri hodnotení náchylnosti územia na zosúvanie. Mineralia Slovaca, 37, No. 4, pp. 529-538.

SAKSA, M., KRIEGEROVÁ, I. (2005): Niektoré možnosti využitia viacrozmerných štatistických metód pri hodnotení prírodných hrozieb. Geomorphologia Slovaca, 2/2005, pp. 30-37.

STANKOVIANSKY, M. (2003a): Geomorfologická odozva environmentálnych zmien na území Myjavskej pahorkatiny. Univerzita Komenského, Bratislava, 152 pp.

STANKOVIANSKY, M. (2003b): Historical evolution of permanent gullies in the Myjava Hill Land, Slovakia. Catena, 51, No. 3-4, pp. 223-239.

VALENTIN, C., POESEN, J., YONG LI (2005): Gully erosion: Impacts, factors and control. Catena, 63, No. 2-3, pp. 132-153.

ZACHAR, D. (1960): Erózia pôdy. SAV, Bratislava, 308 pp.

\section{Z hrnutie}

\section{HODNOTENIE HROZBY VÝMOL'OVEJ ERÓZIE POMOCÍ GEOEKOLOGICKÉHO INFORMAČNÉHO SYSTÉMU (GEIS): PRÍPADOVÁ ŠTÚDIA ZO ZÁPADNÝCH KARPÁT}

Výmolová erózia (vrátane cestnej erózie) je špecifickou formou vodnej erózie. Výrazne sa prejavuje v krajine a jej celkovom charaktere a je najviditel'nejšou formou erózie, ktorá postihuje produkčnú schopnost pôdy. Tým, že vytvára hlboké lineárne formy reliéfu - výmole, limituje rozvoj polnohospodárstva na ornej pôde i na trvalých trávnych porastoch, znehodnocuje nespevnené polné a lesné cesty, utvára komunikačné bariéry.

Cielom tohto článku je hodnotenie hrozby výmolovej erózie v detailnej mierke s využitím empirických dát o prejavoch a charaktere tejto erózie (výmolov a úvozov), geoekologického informačného systému ako integrovaného systému geoekologických informácií a viacrozmerných štatistických metód.

Výmolová erózia bola hodnotená na území o rozlohe $36 \mathrm{~km}^{2}$ v Západných Karpatoch (severozápadnej časti Slovenska), na styku Považského podolia a Strážovských vrchov. Územie pritom zasahuje do 5 fyzickogeografických regiónov nižšieho rádu (Ilavská kotlina, Podmanínska pahorkatina, Butkovské bradlá, Butkovská brázda, Teplická vrchovina) s rôznou náchylnostou na procesy výmolovej erózie.

Tvorba geodatabázy pre hodnotenie hrozby výmolovej erózie metodicky vychádza z koncepcie geoekológie ako integrálnej vedy o krajine, geoekologického výskumu a geoekologického mapovania. Najdôležitejším aspektom je pritom tvorba geoekologického informačného systému (GeIS) ako účelového systému geoekologických informácií a dát (Minár 2003) potrebných pre hodnotenie výmolovej erózie. Základnými jednotkami pri hodnotení potenciálnej náchylnosti študovaného územia na výmolovú eróziu sú abiokomplexy, ktoré predstavujú relatívne homogénne areály z hladiska geoekologických podmienok a tiež stupňa náchylnosti na výmolovú eróziu. Každý abiokomplex je charakterizovaný množinou charakteristík v rámci ucelenej geodatabázy, ktoré môžu mat’ vplyv na inicializáciu výmolovej erózie.

Ďalšie údajové vrstvy geoekologického informačného systému (GeIS) obsahujú informácie o existujúcich prejavoch výmolovej erózie, čiže permanentných výmoloch a úvozoch a tiež líniovými prvkami v krajine náchylnými na výmolovú eróziu. Základnými atribútmi permanentných výmolov a úvozov bola ich celková plocha, hĺbka a stupeň aktivity. Za líniové prvky v krajine náchylné na výmolovú eróziu považujeme najmä nespevnené polné a lesné cesty, suché korytá občasných tokov a medze v rámci ornej pôdy. Odhadovaný bol ich stupeň aktivity, jednak na základe charakteru povrchovej vrstvy, alebo na základe prejavov cestnej erózie. Výsledkom analýzy krajinnej pokrývky a využívania zeme je aj údajová vrstva charakterizujúca typ krajinnej pokrývky a využitia územia.

Samotné hodnotenie potenciálnej náchylnosti študovaného územia na výmolovú eróziu bolo realizované viacrozmernými štatistickými metódami a jedného jednoduchého koncepčnefyzikálneho modelu s využitím údajov geoekologického informačného systému. Pre potreby 
hodnotenia stupňa postihnutia študovaného územia výmolovou eróziou bol pre každý jeden areál abiotického komplexu vypočítaný tzv. index denudácie výmolovou eróziou a podiel plochy výmolov a úvozov na plochu areálu daného abiotického komplexu. Výsledné vyjadrenie náchylnosti územia na výmolovú eróziu vychádza z jednoduchého predpokladu, že čím väčšie je aktuálne pokrytie abiokomplexov daného typu výmol̉mi a úvozmi, tým väčšia je ich náchylnost na vznik nových výmolov a úvozov.

Záverečné hodnotenie aktuálnej hrozby výmolovej erózie bolo vykonávané porovnaním výsledkov potenciálnej (relatívnej) náchylnosti na výmol’ovú eróziu dosiahnutých použitými metódami so súčasnou krajinnou pokrývkou a využitím zeme.

Z porovnania štyroch modelov pre hodnotenie potenciálnej náchylnosti na výmolovú eróziu s reálnymi prejavmi tejto erózie vyplýva, že v troch prípadoch (RA, CA1, MT) existuje signifikantná väzba medzi nimi. Jej velkost’ je však prirodzene obmedzená rozdielom v podstate potenciálnej náchylnosti a reálnej výmolovej erózie, ktorú výrazne ovplyvňuje krajinná pokrývka a spôsob hospodárenia. Významná väzba medzi dvoma štatistickými (RA, CA1) a koncepčne-fyzikálnym modelom (MT) d’alej potvrdzuje relevantnost’ použitia metód viacrozmernej štatistiky pre hodnotenie hrozby výmolovej erózie.

Nazdávame sa, že perspektívny je aj nami načrtnutý postup hodnotenia aktuálnej hrozby výmolovej erózie, nakolko prostá hustota siete výmolov a úvozov (ktoré vznikali v iných podmienkach využívania krajiny v minulosti) sa nedá dnes všeobecne použit ako priamy ukazovatel aktuálnej výmolovej hrozby. Naviac vzhladom na zmeny využitia výmolmi postihnutého územia v minulosti (jeho zalesňovanie) môže byt๋ hustota výmolovej siete dnes už neaktívnych výmolov pri hodnotení aktuálnej hrozby miestami až zavádzajúca.

$\mathrm{Na}$ základe poznania genézy permanentných výmolov možno konštatovat', že väčšina permanentných výmolov v študovanom území je kontrolovaná priebehom antropogénnych líniových prvkoch z minulosti, predovšetkým polných ciest. Niekolko menších výmolových foriem sa vytvorilo v záveroch eróznych zárezov menších vodných tokov. Ich výskyt si vysvetlujeme prítomnostou občasných tokov v humídnejších obdobiach. Výskyt úvozových foriem reliéfu pod permanentnou lesnou pokrývkou dokazuje, že procesy cestnej erózie, ktorá je prvotným štádiom erózie výmol’ovej, nemusia prebiehat nutne len na polnohospodársky využívaných územiach.

Za potenciálne najviac náchylné možno na základe dosiahnutých výsledkov považovat' časti študovaného územia, zasahujúce do Podmanínskej pahorkatiny a Butkovskej brázdy a čast' územia riečnych terás v rámci Ilavskej kotliny. Za menej náchylnú možno považovat’ čast' Butkovských bradiel a najmenej náchylné časti zasahujúce do Trenčianskej vrchoviny a samozrejme rovinné územie nivy Váhu v rámci Ilavskej kotliny. V rámci Podmanínskej pahorkatiny sa nachádza najviac permanentných výmolov, čo súvisí s jej intenzívnym polnohospodárskym využívaním v minulosti. Menej permanentných výmolov sa nachádza v rámci Butkovskej brázdy a najmenej v rámci Butkovských bradiel. Nazdávame sa, že to súvisí s dlhodobým zalesnením týchto území, len čast' z týchto území sa polnohospodársky využíva ako lúky. V rámci lesných porastov sa však nachádzajú početné úvozy ako formy vzniknuté cestnou eróziou.

Aktuálna hrozba výmolovej erózie bola určená na plochách ornej pôdy v rámci Podmanínskej pahorkatiny a terasovej časti Ilavskej kotliny s abiotickými komplexmi s vysokou a vel’mi vysokou potenciálnou náchylnostou na výmol’ovú eróziu a tiež na líniách, najmä polných a lesných cestách s viditelnými prejavmi cestnej erózie (stružky, ryhy, kolaje) a tiež na polných a lesných cestách s nespevneným povrchom a väčším sklonom.

Obr. 1 - Poloha študovaného územia. V legende: štátna hranica, vrstevnice, vodné toky, vodné plochy. Regionálne geomorfologické členenie: hranice oblasti, hranice celku, hranice podcelku, hranice časti. Popisy: celok, podcelok, čast', študované územie.

Obr. 2 - Abiokomplexy, permanentné výmole a úvozy v študovanom území. V legende: hranice geoekologických (prírodných krajinných) typov, hranice abiokomplexov, úvozy, výmole, vodné toky, vrstevnice, kóty (m n. m.).

Obr. 3 - a - Index denudácie (IDn; $\mathrm{m}^{3} / \mathrm{m}^{2}$ ); b - Podiel plochy výmolov a úvozov z celkovej plochy abiokomplexu (RT; \%). Potenciálna hrozba výmolovej erózie: c - RA; d CA1; e - CA2; f - MT. V legende: Potenciálna hrozba výmolovej erózie: velmi nízka, nízka, stredne vysoká, vysoká, vel’mi vysoká. Hranice geoekologických (prírodných krajinných) typov, hranice abiokomplexov, vodné toky, kóty (m n. m.). 
Obr. 4 -Aktuálna hrozba výmolovej erózie. V legende: Líniové prvky náchylné na výmolovú eróziu: s viditelnými prejavmi erózie, bez prejavov erózie; Areály ornej pôdy náchylné na výmolovú eróziu; vodné toky, vrstevnice, kóty (m n. m.), hranice geoekologických (prírodných krajinných) typov.

Authors' affiliations: M. Saksa is affiliated with Soil Science and Conservation Research Institute (SSCRI), Gagarionova 10, 8213 Bratislava 2, Slovakia; e-mail: m.saksa@vupop.sk. J. Minár is affiliated with Comenius University in Bratislava, Faculty of Natural Sciences, Department of Physical Geography and Geoecology, Mlynská dolina 1, 84215 Bratislava 4, Slovakia and with University of Ostrava, Faculty of Science, Department of Physical Geography and Geoecology, Chittussiho 10, 71000 Ostrava-Slezská Ostrava, Czechia; e-mail: minar@ fns.uniba.sk.

Initial submission, 12 December 2011; final acceptance 8 May 2012.

\section{Please cite this article as:}

SAKSA, M., MINÁR, J. (2012): Assessing the natural hazard of gully erosion through a Geoecological Information System (GeIS): a case study from the Western Carpathians. Geografie, 117, No. 2, pp. 152-169. 